\title{
Introduction: the societal dimensions of organized crime
}

\author{
Martin Neumann $^{1} \cdot$ Corinna Elsenbroich $^{2}$
}

Published online: 7 November 2016

(C) Springer Science+Business Media New York 2016

Keywords Introduction to the special issue - Definitions of organized crime - Systemic definition of organized crime $\cdot$ Social norms $\cdot$ Complexity

This special issue presents a collection of papers, based on a conference held in Rome in September 2015. It was the final conference organized by the Global Dynamics of Extortion Racket Systems (GLODERS) research project. GLODERS was directed towards utilizing information technology for the development of simulation models for the understanding of a specific aspect of the global financial system: extortion racketeering. The objective of the conference however, was broader, studying the social aspects of organized crime in general. The conference brought together academics, police officers, legal practitioners and operational specialists for providing scientific evidence to support policy-making and collective engagement. This special issue will allow us to share our new knowledge with an international and interdisciplinary audience. Whilst the focus of GLODERS was on computational approaches to extortion racket systems, the conference resulted from an open Call for Papers and became a highly interdisciplinary event, mirrored in the papers presented here. Contributions shed light on diverse aspects of the interpenetration of the legal and illegal worlds, exploring various methodological, theoretical and conceptual approaches. We hope that the readers will benefit as much as the participants of the conference from the insights provided by the various talks and discussions. Organized crime is an umbrella term for a host of criminal practices, such as trafficking illegal goods and people, extortion, corruption or kidnapping. Organized crime is a global phenomenon

Martin Neumann

maneumann@uni-koblenz.de

Corinna Elsenbroich

c.elsenbroich@surrey.ac.uk

1 University of Koblenz-Landau, Koblenz, Germany

2 University of Surrey, Guildford, UK 
and many criminal organizations and networks operate transnationally. Despite most countries being affected by some form of organized crime, it seems to manifest in different ways in different societies. Understanding these societal dimensions of organized crime will help to understand the phenomenon as well as how to combat it ${ }^{1}$.

\section{Positioning the special issue in the scientific literature}

Speaking of organized crime invokes an ambiguous terminology. For instance legal definitions in Germany regard organized crime as planned criminal acts of two or more persons whereas the Italian law already penalized the membership in Mafia-type organizations (von Lampe 2013). Thus even in law the concept of organized crime varies between an emphasis on criminal activities and criminal organizations. The very term 'organized crime' itself emerged at the beginning of the 20th century in the USA (von Lampe 1999). In Chicago in 1919 a reform commission, the Chicago Crime Commission promoted reforms to increase the efficiency of the criminal justice and curtail prostitution. Motivation for founding the commission was notorious pay roll robbery. Chicago had the reputation of an extremely corrupt city, an inefficient public administration and an alleged 'criminal class' consisting of a network of corrupt public administration, unions and mobsters (von Lampe 2001). Thus the concept of organized crime can be described as 'systemic', pointing towards the social conditions fostering emergence of crime.

During Prohibition the meaning changed quickly to denote big crime syndicates, symbolized by names such as Al Capone. The change in the perception of social reality implied a change of proposed concepts and measures to combat the phenomenon from reform to strict law enforcement and punitive measures (von Lampe 2001). After World War II the concept of organized crime underwent further changes, including a picture of an ethnically homogeneous Italian Mafia with sophisticated organizational structures penetrating the US and an extension of the Mafia model to organizations of other origin (such as Latin-America) or social background (such as outlaw motorcycle gangs). This concept of organized crime can be described as focusing on the organizational structure of illicit business organizations (paradigmatically Cressey 1969, 1972).

However, the development of the concept of organized crime did not remain unambiguous. At all times the demand of illegal markets, such as the drug market, had been served also by petty criminals and small groups. Therefore law enforcement agencies preferred to include small and undifferentiated gangs under the heading of 'organized crime'. This calls

\footnotetext{
${ }^{1}$ Certainly this special issue would not have been possible without the help of many individuals and organizations. First of all, the GLODERS project received funding from the European Union's Seventh Framework Programm (FP7/2007-2013) under grant agreement $n^{\circ} 315874$. Without this support, nothing would have happened. The project was initiated by Rosaria Conte and we would like to dedicate this special issue to her memory. Furthermore the success of the conference would not have been able without the effort and help of the local organizers Giulia Andrighetto, Federica Mattei and many helping hands, as well as the scientific chairs Corinna Elsenbroich and Nigel Gilbert. We would like to thank all authors for contributing their labor for this special issue. Moreover, it cannot be underestimated that these contributions benefitted from the laborious work of numerous reviewers who provided their expertise to increase the scientific quality of all the contributions. Last but not least we would like to thank Trends in Organized Crime for providing the platform to publish these papers. In particular we would like to thank chief-editor Klaus von Lampe for continuous constructive help and advice.
} 
for a concept that does not focus on organizational structures of big crime syndicates to be perceived as 'organized'. Rather it is sufficient that a somehow planned joint activity is undertaken by a group of any size as it can be found for instance in the German legal definition of organized crime. Rather than studying organizations this approach to organized crime can be characterized as focused on the activity of organizing (Hobbs 2001), i.e. joint criminal activities (von Lampe 1999, 2013).

Thus concepts of organized crime might focus on systemic aspects, organization and activity (von Lampe 2001). It shall be noted that the latter ones include a - more or less strict - differentiation between the legal and the illegal world whereas the systemic approach particularly asks for the social dimensions of organized crime (see also Kleemans and van de Bunt 1999).

Remarkably, the concept of organized crime only slowly migrated outside the USA. For instance, while the Italian Mafia is often perceived as paradigmatic for organized crime, in Italy the existence of the Mafia as an organization has been denied for a long time (Dickie 2007). Only with the so-called maxi trials in the 1980s did witnesses such as Tommaso Buscetta show that Cosa Nostra had a highly differentiated organizational structure (Paoli 2003; Dickie 2007). The maxi trials had been instantiated after the murder of the communist politician Pio La Torre in April 1982. La Torre was the first to demand that being a member of the Mafia should be prosecuted as a criminal offence, now a normal part of Italian law. In fact, only the assassination provided the political atmosphere to realize this legislation. The maxi trials were the first big criminal proceedings against the Mafia in which 360 of 474 accused were convicted (Dickie 2007).

In this special issue we adopt a broad characterization of the term organized crime. As already the Chicago Crime Commission in 1919 emphasized the complexity of interrelations between the legal and the illegal world, the objective is to highlight:

1) the impact of organized crime on society;

2) the relations between society and organized crime;

3) what organized crime can tell us about society and

4) how to combat the influence of organized crime on society.

For instance, one article investigates loan sharking in the city of Rome. Whilst not necessarily the case, often the lenders have further connections to financially strong groups of organized crime such as the Italian mafia-type organizations. In principle it might just be a relation between the lender and the borrower. However, illegal lending is a widespread, culturally embedded social practice of day-to-day relations including emotional states and motivational background (for social practice theory see Bourdieu 1972; Giddens 1984; Schatzki 2002; Reckwitz 2002). This interweaving of different individuals, organizations, norms, cultures and practices is an example of the systemic approach towards organized crime taken here. A number of articles investigate the relation between society and criminal organizations in systemic extortion. This research highlights the importance of 'bottom-up' approaches of civil society resistance for combating extortion. Also here the focus is on the interrelation between the various legal and illegal domains of society. Thus this special issue has a certain focus on systemic aspects of the interface between the upper world and the underworld (Schelling 1967). This is by no means meant as a judgment on the value and impact 
of other approaches; rather the aim is to highlight the potential for further research in this domain. On the one hand the impact of organized crime includes, but is not limited to, extortion, corruption and undermining the financial system by providing liquidity in particular for small companies. On the other hand, research also provides policy advice for combating organized crime by facilitating collaboration of science and criminal investigators, including the development of new technological tools for providing scientific expertise for policy interventions. These aspects are highlighted in this special issue.

\section{Overview of the contributions to this special issue}

Investigating the social, cultural and economic conditions fostering or hindering organized crime is inherently multidisciplinary research (von Lampe 2006). Extending the focus beyond studying organizational aspects of criminal organizations (as the 'organizational' definition of organized crime suggests) calls for insights from all domains of the social sciences. This special issue covers a wide range of innovative approaches to the study of the societal dimensions of organized crime: ranging from social network analysis via narratives of cultural representations and in-depth qualitative interviews following a cultural anthropology approach to agent-based simulation of social complexity. The first two papers focus on networks and their analysis. While the first one provides an overview of directions for future research, the second describes an advanced computational tool for the detection and analysis of covert networks to support forensic investigations. The following five papers apply agent-based modeling to the study of organized crime. The first sketches an application for policy advice to combat corruption. The next papers focus on the Sicilian Mafia. While the first two of these continue the issue of utilizing a modeling approach for policy interventions, the next two papers have a more theoretical focus. The first model conceptualizes extortion rackets as collective cooperation problems. The next one is studying internal relations of a criminal organization as a role model of the emergence and decline of social order. This is followed up by two papers drawing upon a perspective of cultural anthropology on organized crime, applying qualitative methodologies. First, a critical examination of cultural representations of the Mafia is provided based on an analysis of journalistic narratives. While remaining in Italy the special issue closes with a case study of indepth interviews of victims of loan sharking in the city of Rome. We continue with a brief sketch of the individual articles.

The paper 'The Shaping of Covert Social Networks: isolating the effects of secrecy' by Nigel Fielding provides an overview of network research in criminology. Fielding asks whether and how networks in organized crime differ from legal business networks. Thereby the specific condition of covertness of criminal networks is highlighted. Starting point for the examination is Cressey's traditional approach of studying organized crime by the degree of functional differentiation. Cressey supposed that analogous to the legal world also organized crime is characterized by a tendency of increasing differentiation. However, more recent research has put this model into question. Criminal networks tend to be flexible and adaptive. This provides a challenge for law enforcement as it might not be sufficient to take out one 'Mr. Big' as in highly centralized networks. On the other hand, the condition of covertness is a challenge for 
the criminal network itself, as criminals need to balance the trade-off between efficiency and secrecy. This leads to the question for current research whether indicators of network characteristics such as degree of centralization (or decentralization, respectively), density, strong and weak ties etc. enable the identification of the separation of criminal networks from the legal world or the resilience of criminal networks. It remains a question for future research what structural features differentiate overt and covert networks.

The paper 'By investigation, I mean computation. A framework to investigate the societal dimension of crime' by Lettieri, Malandrino and Vicidomini describes the tool CrimeMiner for the adoption of data mining technologies and network analysis in the practice of public prosecutors. In the current information age the key problem is turning information into knowledge. One solution to this problem is visual analytics combining several branches of computer science and artificial intelligence research such as visualization, human-computer interaction, and data mining. CrimeMiner is lauded as a user-friendly tool that is intended to bring computation to the core of criminal investigations. The main body of text describes the workflow and functionalities of the tool. CrimeMiner brings together the stages of the creation of documents, data management and analysis. It calculates standard indicators of social network analysis such as centrality measures, enables visualization and much more. Finally, a case study is documented as a test case.

Olaya, Guzman, and Gomez-Quintero are the first of a series of papers documenting simulation models. The paper on 'An Engineering Perspective for Policy Design: SelfOrganizing Crime as an Evolutionary Social System' investigates policy interventions against corruption. They use the example of public procurement in Colombia to illustrate the emergence and persistence of corruption. Corruption is modeled as a knowledge dynamics. Knowledge is modeled by rules, and dynamics of knowledge is modeled by the evolution of the rule system. Variation and selection of rules is a selforganizing process. In Colombia, $17 \%$ of public contracts involve bribes whereby the majority of bribery is due to a request from a public officer. Control systems against this practice are provided by the local government, prosecutors and citizens' complaints. In the model these are implemented as agents that interact according to certain rules, including various corrupt rules. The simulation allows exploring the evolution of corrupt rules over time, in particular in reaction to different policy interventions. These include bottom-up reactions by citizens and top-down enforcement of governmental control. Different interventions have different effects on the population of different corrupt rules which Olaya et al. use to suggest guidelines for an iterative process of policy design.

Also the paper 'GLODERS-S: A Simulator for Agent-Based Models of Criminal Organizations' by Nardin, Székely, and Andrighetto contributes to policy advice. By means of the agent-based simulator GLODERS-S they investigate the effectiveness of different strategies for combating extortion rackets. The model is calibrated against the history of the Sicilian Mafia. The authors show that agent-based modeling is an established tool for studying various policy domains and is particularly effective for the examination of effects of interventions by integrating mental and social processes. They argue that these features provide a powerful tool for criminological analysis of policy design. The main part of the paper describes the simulator, consisting of Mafiosi, entrepreneurs, consumers, NGOs and the state, and how the model can be configured to 
various scenarios. For instance, entrepreneurs may be more or less prone to obey extortion requests or the state may follow a more or less rigorous anti-Mafia strategy. Finally the potential for policy advice is demonstrated by implementing different policy strategies: Similar to Olaya et al., effects of a top-down strategy of increasing law enforcement, employed by the state, and a combination with a bottom-up strategy of changing social norms, typically employed by NGOs are investigated. While both strategies are successful, the latter is more resilient.

The contribution of Troitzsch 'Can agent-based simulation models replicate organized crime?' is directly related to Nardin et al.. While Troitzsch investigates the same extortion phenomenon as Nardin et al., i.e. the Sicilian Mafia, the analysis has a different focus: By differentiating replicative, predictive and structural validity Troitzsch asks whether agent-based simulation models can replicate empirical data. First the parameter space of the model is explored by a Monte Carlo simulation in which parameters are randomly varied in a huge number of simulation runs. The finding is that prevalence of traditional or civic norms in the society are most important for explaining variance of outcomes. This finding is then compared to various sources of empirical data, ranging from anecdotal evidence, a data base of extortion in various South Italian provinces, to the European Value Study (EVS) to investigate whether Southern Italy is a realization of the stochastic universe of the Monte Carlo simulations. As indicators for traditional and civic norms in EVS, a group of items deal with the values most important to teach to children, namely obedience on the one hand and responsibility on the other hand. In fact, in Southern Italy the importance of obedience (as an indicator for traditional norms) is more pronounced than in other regions. The result is that the simulation produces cases which correspond to undetected cases in reality. Hence the percentage of undetected cases among all simulated cases can be understood as a theory-dependent estimate of the dark figure.

Also Elsenbroich's contribution about 'The Addio Pizzo Movement: Exploring Social Change using Agent-based Modelling' addresses the relation between extorters and extorted entrepreneurs using the Sicilian Mafia as an example. The Addiopizzo movement is a Sicilian Anti-Mafia NGO already featured in Nardin et al. Elsenbroich goes deeper in the details of the extortive relation, in particular the reaction of entrepreneurs on extortion requests, by conceptualizing the extortion situation as a collective cooperation problem akin to the Tragedy of the Commons (Hardin 1968). The paper is a theoretical examination of the effects of resistance against extortion by framing entrepreneur's decision making in a form of collective reasoning. While applying a game theoretical approach several different strategies of reaction are compared to examine when entrepreneurs are acquiescent and when they become resistant: from the side of the entrepreneurs individual utility considerations are opposed to social norms and collective reasoning. From the side of the extorter costs of punishing resistant entrepreneurs and police surveillance are examined. Collective reasoning is implemented by entrepreneurs taking not only individual costs of extortion into account but the cost of all members of a team in a utility function. Thus while agent-based modeling as well as game theory is focused on individualistic reasoning, in the model socially transmitted resistance is an important means for fighting extortion. This is an essential clue for the mechanisms by which NGOs might become effective in the real world.

While Elsenbroich investigates the extorted and the process of extortion in more detail, the contribution of Neumann, Lotzmann and Troitzsch focuses on the extorting 
organization. The paper 'Mafia war: Simulating conflict escalation in criminal organizations' perceives criminal organizations as a laboratory for studying stability of organizational differentiation. Thus the focus is on internal relations within a criminal organization. Again using the example of the Sicilian Mafia the paper describes a simulation model of the outbreak of so-called Mafia wars and the re-establishment of organizational hierarchies. Wars are instances of a collapse of hierarchical structures which provide an authority with certain internal legitimacy as a sanctioning institution. In the wars individual Mafia 'families' take justice and violence in their own hands and the organization falls back into a Hobbesian state of anarchy. In Monte Carlo simulations the stochastic universe largely remains peaceful. However, under certain conditions the model replicates the outbreak of war. A statistical analysis identifies cycles of revenge as central mechanisms for the collapse of a sanctioning authority. This is a highly path-dependent effect in which small initial differences can generate great variation in simulation histories. Empirically two wars took place for very different reasons. Different types of simulated histories can be differentiated which resemble different empirical instances.

With the contribution of Phillips on 'Corrado Alvaro and the Calabrian Mafia: a critical case study of the use of literary and journalistic texts in research on Italian organized crime' we leave the methodological domain of simulation but retain the substantive topic of the Italian Mafia. Phillips examines the cultural representations of the Calabrian Mafia, 'Ndrangheta. Research on the history of 'Ndrangheta relies to a substantial degree on literary and journalistic texts. This calls for an investigation of the representation of socio-cultural history in these sources. For this purpose Phillips draws on the case of a much cited text of the Calabrian writer Corrado Alvaro, written for the newspaper Corierre della sera in 1955. Today the text is frequently cited by Anti-Mafia activists as the starting point of resistance. Phillips puts this interpretation into question by placing the text in the contemporary cultural context: As criticizing the Mafia would invoke prevalent negative stereotypes about Southern Italy, in contemporary fictional representations the Mafia is often portrayed as representing a traditional moral code, opposed to the moral corruption by modern capitalism. This background needs to be taken into account when judging journalistic texts. In fact, Alvaro's description of organized crime in his fictional texts is also prevalent in the journalistic text. Violence is downplayed and a tension between the traditional and modern, capitalistic Mafia is invoked. This substantially influenced later representations of the Mafia but cannot be seen as a straightforward reflection of historical facts.

Finally Marinaro's paper on 'Loan sharking in a time of crisis' highlights the various aspects of an illegal financial market in a case study of the city of Rome. For this purpose a triangulation of in-depth interviews with victims of usury, as well as NGOs, statistical data, public documents, and internal institutional reports is applied. In particular after the financial crisis of 2008 organized crime penetrated the legal economy. However, while financial activities of organized crime groups are increasingly the focus of scientific investigations as well as public attention, illegal money lending still is rarely investigated from the side of local demand, in particular by small entrepreneurs. While loan sharking might become a debt-trapping predatory practice it is often necessary for survival, in particular for small entrepreneurs. After the 2008 credit crisis banks became reluctant to give credits to enterprises with small margins. 
Therefore turning to illegal lenders is often the only short term solution for pressing problems. Marinaro investigates how local social norms on the micro level are interwoven with macro level effects of legislation and globalized economy. On a local level the legal and legitimate do not coincide. It is necessary to differentiate a subjective perception of lenders as helping or exploitative. However, victims are stigmatized like drug addicts. While legislative measures exist their theoretical goals have not been translated into practice due to complicated bureaucratic processes and a slow juridical system.

\section{Some central insights of this special issue}

Before summarizing and synthesizing the key points from this collection of papers we would like to discuss a potential limitation: while the issue is not restricted to a particular country, many of the contributions provide an overview of the different facets of Italian organized crime. We feel, however, that the findings might well be generalized beyond a particular country, in particular given the paradigmatic role the Italian Mafia plays in organized crime. It might be convenient to distinguish two dimensions: One dimension addresses key questions at the core of organized crime research. This might be denoted as 'intra-disciplinary' contributions of this special issue. The other dimension sheds light on the specific interdisciplinary nature of the investigation of the systemic interlocking of crime and society.

\section{Intra-disciplinary contributions to organized crime research: transnational and local dimensions}

In the recent decade research on organized crime has emphasized the global dimension of organized crime, coined by the term transnational organized crime (Madsen 2009; UNODC 2010; Allum and Gilmour 2015). Transnational organized crime points to one of the dark sides of globalization (Heine and Thakur 2011). Certainly the Italian Mafia in the USA undertook transnational operations already in the 1950s. By definition smuggling has always been a transnational activity. However, it is claimed that the recent globalization of information technology, financial economy and transportation infrastructure expanded opportunities for and eased the realization of criminal activities (Madsen 2009). Often organized crime is perceived as intimately related to globalization. Certainly this threat cannot be underestimated. For instance in times of a globalized financial economy professional money laundering can hardly be distinguished from legal financial transactions (Quirk 1997; Neumann and Sartor 2016). However, as already Campana (2011) remarked, at least certain types of organized crime cannot easily migrate. Campana demonstrates this by the example of extortion racket systems. This finding holds also for the contributions in this special issue that investigate extortion as well as the fight against extortion by local entrepreneurs and NGOs such as Addiopizzo: extortion as well as local resistance are bound to established social relations and networks of trust. For instance, the contributions of Nardin et al. and Troitzsch build upon perceived and observed reactions towards extortion. This refers to a local radius of perception in neighborhood relations. The same holds for team 
reasoning (see Elsenbroich in this special issue): Extending the mind requires bonds of trust that can only grow in close social relations. While these might develop in various ways trust grows most easily on a local base. Likewise while for instance social relations in networks of corruption undermine generalized trust (Uslander 2005), they build upon trust between corruptor and corrupted that cannot easily be transferred to interactions between strangers (Jiang et al. 2015). The same holds for loan sharking in the city of Rome (see Marinaro in this special issue). While loan sharks may possess a transnational network of financial investors the relations to the debtor turned out to be based on sometimes rather personal neighborhood relations. Thus the case studies in this special issue show also a - partly very local - dimension of organized crime. Even in the 21th century instances of organized crime exist that preserve a local base.

\section{Intra-disciplinary contributions to organized crime research: victims of organized crime}

A number of contributions to this special issue problematize the concept of the victim. Typically victimization studies emphasize vulnerability of victims for various reasons (Killias 1990; Jackson 2008; Anzola forthcoming). This may be due to distance from the state or core society such as it is sometimes the case in migrant communities or being a stigmatized population such as prostitutes. Research highlights massive stress and a sense of powerlessness caused by becoming victimized (Anzola forthcoming). This is confirmed by the studies in this special issue. In particular Marinaro's contribution shows how victims of loan sharking practices get trapped in cycles of usury causing shame and stigmatization. However, already Gambetta (1993) and Varese (2014) indicate that for instance mafia-type organizations often execute a business of violent protection. Thus they also provide some kind of service, even though in case of mafia-type organizations the threat which they repel is caused by the organization itself. In a similar vein, Marinaro shows that illegal lenders serve a demand that is not appropriately served by the legal banking system. In fact illegal lenders are not necessarily exploiting, even though - dependent on the interest rate - they often are. As in any illegal market suppliers serve a demand. In case of loans the demand is not even illegal in principle. Thus the practice can be perceived as a result of market failure.

For loan sharking, the legal and the legitimate do not coincide. On the one hand it is a gateway into the legal economy for mafia-type organizations with huge financial assets. On the other hand the debtors are highly stigmatized and often subject to psychological traumata as described in the literature on victimization. Despite this it has to be emphasized that the situation is one in which the debtor actively approaches the lender rather than being passively victimized. At least sometimes illegal lenders are perceived as helping rather than as exploiting. This implies a debate on the concept of victim. Implicitly this can be found in various contributions to this special issue. It is well-known that in cases of a weak state and weak law enforcement agencies the business of protection by mafia-type organizations entails also a service for society (comp. from a certainly biased perspective Arlacchi 1993) that partly is perceived as legitimate and justified (see Phillips in this special issue). For this reason the contribution of Nardin et al. explicitly considers a benefit that possibly can be generated by the criminal organization. Thus also in this contribution the status of the victim remains 
ambiguous. If the entrepreneur follows so-called 'traditional norms' (see also Troitzsch in this special issue) the extortive request is subjectively perceived as legitimate. Likewise in cases of corruption (see Olaya et al. in this special issue) the status of a victim is not always unequivocal. The scale of corrupt activities varies greatly (Heywood 2015). Certainly if a customer is forced to pay a bribe the customer becomes victim of an offence. Things become more blurred if the customer receives a special treatment in return, for instance by getting a university degree or privileged treatment in a hospital. Finally instances of systemic corruption (Doig and Theobald 1999) might even produce a win-win situation for both the corruptor and the corrupted (Bannenberg and Schaupensteiner 2004). In this case it is the general public that suffers the damages caused by corruption by losses in economic development or inefficiency of the public sector (Heywood 2015). The moral hazard becomes structured as a public goods dilemma (Ostrom 1990). In turn the victim cannot always be identified unambiguously. Rather the notion of a victim is a multifaceted phenomenon. A somewhat different aspect of the concept of victim is discussed in Neumann et al.: namely the fact that criminals are particularly vulnerable to become victims of criminal offences (see also van Putten 2012). While research approaches criminals predominantly as offenders, they are also potential victims. Neither criminals nor smooth operation of criminal organizations is protected by the state monopoly of violence. For this reason violence or the threat of violence is a common practice in the underworld (Hofmann and Gallupe 2015). It can be summarized that in systems where crime and society closely interrelate, the divide between victim and offender becomes blurred and might be topic of further examination.

\section{Interdisciplinary theoretical innovation: social norms}

Problematizing the role of victims leads to the field of norms regulating patterns of interaction. Organized crime does not operate in a vacuum. In particular a systemic approach to organized crime, asking for the complex interlocking of society and organized crime, calls for explanatory accounts from all domains of the social sciences (von Lampe 2006). On a theoretical level we highlight in particular the sociology of norms as a genuine sociological theoretical concept contributing to the study of organized crime. A number of contributions to this special issue implicitly or explicitly invoke the concept of norms. For instance the relations between debtor and lender in loan sharking (see Marinaro in this special issue), are implicitly regulated by social norms. Likewise systems of corruption (see Olaya et al. in this special issue) penetrate the manner in which social relations in civil society are shaped, i.e. influence social norms. Corruption research emphasizes that legislative measures are not sufficient in combating corruption but rather change of motivations and thus social norms is highly important (Carr 2007). Moreover, a number of contributions investigate extortive relations between criminal organizations and entrepreneurs in the civil society. These likewise raise the question of social norms regulating the relations between society and organized crime.

Norms are a central term in sociological theory. At the interface between the individual and society, norms are both a cognitive and a social concept. On the one hand, norms are enacted by individual habits and behavior. Typically this includes a 
subjective belief about a prescribed or prohibited behavior in a certain situation (Bicchieri 2006). This is the cognitive element of norms. On the other hand norms are a behavioral regularity among groups and thus a macro-level effect generated by interactions of individual actors (Ullmann-Margalit 1977; Coleman 1990). This ambiguity is reflected by different theoretical accounts of norms that can be distinguished by a macro- or micro-social perspective. Very broadly theories of norms can be summarized as role theoretical, or following an approach of identity theories or rational choice (Bicchieri and Muldoon 2014). Rational choice is in particular a theory of norm enforcement with the concept of sanction or punishment as central theoretical terminus. Since norms regulate interactions between individuals, a rational choice account is often framed within the concept of game theory as a theory of strategic interaction (Binmore 1998; Voss 2001, see Elsenbroich in this special issue).

How the theory of norms is relevant for organized crime research and in particular for studying the systemic interlocking of society and organized crime can be demonstrated by taking an extortive request as an example: An individual facing such a request may believe that fulfilling the request is either a prescribed or a prohibited behavior; either case is a normative belief. Therefore the contributions of Nardin et al. and Troitzsch in this special issue differentiate between so-called traditional and civic norms. The notion of traditional norms stands for the believe that victims are obliged to fulfill the extortion request, the so-called pizzo, as it has been typical in Sicilian society for a long time (and to a large degree still is). Civic norms on the other hand represent the belief that it is prohibited to fulfill an extortive request. This raises the question of norm change, a central puzzle since the beginning of sociological research (Durkheim 1893; Eßbach and Pohlmann 2006). For instance, a Sicilian entrepreneur testified the reason for breakingup with paying pizzo that "I did it mainly for my children [...]. I was embarrassed for them. How is it possible, after having brought them up to respect the rules and the civicness, to say to my son: there's Uncle Pino, and every month you have to give him an envelope with €2000" (Neumann et al. forthcoming). This testimonial indicates that moral reason plays a crucial role in normative change. However, social embedding of certain convictions is equally important as norms are already by definition a regularity of certain patterns of behavior. For instance, in the case of Sicily a number of civil society organizations such as Libera or Addiopizzo emerged which promote a culture of legality (see Elsenbroich in this special issue). This refers to the role of civil society. Civic engagement presupposes as well as promotes trust in society whereas embedding of organized crime builds on a culture of distrust (Gambetta 1990). Extending beyond the particular example of extortion racket systems, it can be summarized that the embedding of organized crime in the society crucially depends on the normative structure of the society. Therefore combating organized crime crucially also depends on bottom-up engagement of the local population (see Nardin et al. or Olaya et al. in this special issue). In sum, a number of contributions suggest the usefulness of studying particular aspects of organized crime through the lens of sociological theories of norms.

\section{Interdisciplinary methodological innovation: complexity}

Finally, the methodological plurality of the various contributions is noteworthy. While social networks and cultural anthropology have become established methodological 
innovations in the toolbox of organized crime research (von Lampe 2006), contributions utilizing agent-based modeling are more rarely found in the criminological literature (however see Liu and Eck 2008; Birks et al. 2012, 2014; Malleson and Evans 2013). Therefore we highlight some features of this approach that might be useful to explore in future research. Agent-based models are computer simulations of systems of autonomous software objects (called 'agents') that interact according to their own rules within a simulated environment (Davidsson 2002; Gilbert 2007). Systems of many interacting elements are denoted as complex systems. If the elements react to changes in the environment the system is called adaptive complex system (Holland 2006). Often this includes schemes for responses to changes in the surrounding environment. Complex systems research originates from non-linear physics. A typical example is meteorology, studying a system of many interacting particles in the atmosphere. Obviously society is no less complex than the particle dynamics of the weather, as humans are autonomous, capable of self directed behavior. This is a typical example of an adaptive complex system. Not surprisingly, therefore the complex systems approach has been seeing various applications in the social sciences ranging from psychology (Novak et al. 1998; Dörner 2005), to political science (Banerjee et al. 2014), sociology (Castellani and Hafferty 2008) and economy (Brian 2014).

Characteristic for the interaction of many autonomous entities in complex systems are dense and recursive causal relations (Wimsatt 1994) that generate specific system behaviors (Homer-Dixon et al. 2013): non-linear effects, meaning that cause and effect are not proportional to each other. Small causes may have huge effects and relations between cause and effect may be shaped in $\mathrm{S}$ or $\mathrm{U}$ form. Often complex systems are also characterized by emergence, broadly speaking denoting that the whole is more than the sum of its elements (DeLanda 2015). Moreover, if they reach an equilibrium state at all, complex systems typically have multiple equilibria in the system's state space. Sometimes a certain equilibrium state might be rather stable once the system has fallen into its basin of attraction. In other instances an equilibrium might be rather unstable and small exogenous shocks may push the system away from the equilibrium. Closely related is the issue of path dependency which is a characteristic of complex systems that can be described as historical contingency of the system's state.

All these features can also be found in various aspects of social systems. Some aspects shall be highlighted that suggest studying the systemic interlocking of organized crime and society through the lens of complex systems theory. More specifically the relation between the upper and the underworld may be perceived as an adaptive complex system: Certainly both the society as well as criminal organizations react to changes in the respective other domain. Often the reaction is triggered by a scheme for responses to changes in the surrounding environment. This may be for instance a cultural memory (Halbwachs 1950) as representation of e.g. the Mafia which fosters certain perceptions of and in turn reactions to Mafia activities (see Phillips in this special issue). Likewise, drug trafficking may be guided by certain routines for handling risks and protecting leadership (Hofmann and Gallupe 2015) as obviously criminal organizations have no direct access to information about policy surveillance. The analogy (see von Lampe 2006 for the use of analogies) between complex adaptive systems and the social dimensions of organized crime can be strengthened by examples of how organized crime exhibits characteristic features of complex systems. Certainly the relations between legal and illegal activities are characterized by dense and 
recursive causal patterns. Thus they are constituted by mechanisms which generate complex systems. In fact, they also exhibit patterns that are characteristic features of complex systems. An example for non-linear effects is the comparably sudden switch in the perception of and reaction to Mafia activities in Southern Italy. While for a long time the Mafia has been accepted as quasi legitimate authority, in about the 1990s the situation changed and at least Palermo faced the emergence of a culture of legality (see Nardin et al. in this special issue and in more detail Nardin et al. 2016). This highlights already the next characteristic of complex systems: emergence. Moreover, the rather sudden switch indicates a system with multiple equilibria. In general a social system might be trapped in a defective equilibrium such as extortion racket systems (as highlighted by a number of contributions to this special issue) or corruption (see Olaya et al. in this special issue). In this case it is a probabilistically unlikely event, requiring patience and a lot of effort to push the system away to a different semi-stable state such as compliance with legal norms. On the other hand, the persistence of criminal networks operating outside the state monopoly of violence may be characterized as a rather unstable equilibrium (see Neumann et al. in this special issue). The stability of extortion racket systems can be explained by path dependencies (see Troitzsch in this special issue) that are interlocked by a history of cultural representations that shapes the view on the Mafia (see Phillips in this special issue). Thus the systemic interlocking of crime and society is constituted by mechanisms generating complex systems as well as exhibiting the properties of complex systems.

Finally in an agent-based model different kind of actors such as the state, criminals or NGOs can be implemented and their interaction can be studied during simulation runs. This enables integration of different explanatory accounts such as top down and bottom up accounts for combating organized crime (see Olaya et al. and Nardin et al. in this special issue). Moreover, models provide a virtual lab for examining policy interventions that otherwise would hardly be possible and certainly ethically dubious (again see Olaya et al. and Nardin et al. in this special issue).

Compliance with ethical standards The research leading to these results has received funding from the European Union Seventh Framework Programme (FP7/2007-2013) under grant agreement no. 315874 ("Global dynamics of extortion racket systems").

The authors declare that they have no conflict of interest.

This article does not contain any studies with human participants performed by any of the authors.

\section{References}

Allum F, Gilmour S (ed.) (2015) The routledge handbook of transnational organized crime. Routledge, London

Anzola D (forthcoming) Basic dynamics of extortion racketeering. In Elsenbroich C, Anzola D, Gilbert N (eds.). Social Dimensions of Organized Crime. Springer, New York, pp. 33-61

Arlacchi P (1993) Men of dishonor: inside the Sicilian Mafia: an Account of Antonino Calderone. William Morrow

Banerjee S, Ercetin S, Tekin A (eds) (2014) Chaos theory in politics (understanding complex systems). Springer, Berlin

Bannenberg B, Schaupensteiner W (2004) Korruption in Deutschland. Verlag C.H. Beck, München

Bicchieri C (2006) The grammar of society: the nature and dynamics of social norms. Cambridge University Press, New York 
Bicchieri C, Muldoon R (2014). Social Norms. In Zalta E (ed.). The Stanford Encyclopedia of Philosophy (Spring 2014 Edition), URL = <http://plato.stanford.edu/archives/spr2014/entries/social-norms/>

Binmore K (1998) Game theory and the social contract. MIT Press, Cambridge

Birks D, Townsley M, Stewart A (2012) Generative explanations of crime: using simulation to test criminological theory. Criminology 50(1):221-254

Birks D, Townsley M, Stewart A (2014) Emergent patterns of interpersonal victimisation: an agent-based approach. J Res Crime Delinq 51(1):119-140

Bourdieu P (1972) Esquisse d'une théorie de la pratique, précédé de trois études d'éthnologie kabyle. Droz, Geneva

Brian A (2014) Complexity and the economy. Oxford University Press, Oxford

Campana P (2011) Eavesdropping on the Mob: the functional diversification of Mafia activities across territories. Eur J Criminol 8(3):213-228

Carr I (2007) Fighting corruption through regional and international conventions: a satisfactory solution? European Journal of Crime, Criminal Law and Criminal Justice 15(2):121-153

Castellani B, Hafferty F (2008) Sociology and complexity science: a new field of inquiry (understanding complex systems). Springer, Berlin

Coleman J (1990) Foundations of social theory. Belknap, Harvard

Cressey DR (1969) Theft of the nation: the structure and operations of organized crime in America. Harper \& Row, New York

Cressey DR (1972) Criminal organization: its elementary forms. Harper \& Row, New York

Davidsson P (2002) Agent based social simulation: a computer science view. J Artif Soc Soc Simul 5(1)

DeLanda M (2015) Philosophy and Simulation. The emergence of synthetic reason. Bloomsbury, London

Dickie J (2007) Cosa Nostra: a history of the Sicilian Mafia. Hodder \& Stoughton, London

Doig A, Theobald R (1999). Introduction: why corruption? Commonw Comp Polit. Special issue: Corruption and democratization 37(3):1-12

Dörner D (2005) Reise ins innere der blackbox - bewusstsein als computersimulation. In: Herrmann C, Pauen M, Rieger J (eds) Bewusstsein: Philosophie, Neurowissenschaften, Ethik. Fink, München, pp 309-328

Durkheim É ([1893] 1992) Über soziale Arbeitsteilung. Studie über die Organisation höherer Gesellschaften. Suhrkamp, Frankfurt a. M

Eßbach W, Pohlmann F (eds.) (2006) Heinrich Popitz: soziale Normen. Suhrkamp, Frankfurt a.M

Gambetta D (1990) Mafia: the price of distrust. In: Gambetta D (ed) Trust: making and breaking cooperative relations. Basil Blackwell, Oxford, pp 158-175

Gambetta D (1993) The Sicilian Mafia: the business of private protection. Harvard University Press, London Giddens A (1984) The constitution of society. Outline of the theory of structuration. Polity Press, Cambridge Gilbert N (2007) Agent-based models. SAGE Publications, London

Halbwachs M (1950) La Mémoire collective. Presses Universitaires de France, Paris

Hardin G (1968) The tragedy of the commons. Science, New Series 162(3859):1243-1248

Heine J, Thakur R (eds.) (2011) The dark side of globalization. United nations university press, Tokyo.

Heywood P (2015) Introduction: the scale and the focus in the study of corruption. In: Heywood P (ed) Routledge handbook of political corruption. Routledge, London, pp 1-13

Hobbs D (2001) The firm: organizational logic and criminal culture on a shifting terrain. Br J Criminol 41(4): $549-560$

Hofmann D, Gallupe O (2015) Leadership protection in drug-trafficking networks. Glob Crime 16(2):123138

Holland J (2006) Studying complex adaptive systems. J Syst Sci Complex 19(1):1-8

Homer-Dixon T, Maynard J, Mildenberger M, Milkoreit M, Mock S, Quilley S, Schröder T, Thagard P (2013) A complex systems approach to the study of ideology: cognitive-affective structures and the dynamics of belief systems. J Soc Polit Psychol 1(1):337-363

Jackson J (2008) Bridging the social and the psychological in the fear of crime. In: Lee M, Farrall S (eds) Fear of crime: critical voices in an age of anxiety. GlassHouse Press, New York, pp 143-167

Jiang T, Lindemanns J, Bicchieri C (2015) Can trust facilitate bribery? Experimental evidence from China, Italy, Japan, and The Netherlands. Soc Cogn 33(5):483-504

Killias M (1990) Vulnerability: towards a better understanding of a Key variable in the genesis of fear of crime. Violence Vict 5(2):97-108

Kleemans ER, van de Bunt H (1999) The social embeddedness of organized crime. Transl Organized Crime 5(1):19-36

Liu L, Eck J (eds.) (2008) Artificial crime analysis systems: using computer simulations and geographic information systems. Idea Group Publishing, Hershey

Madsen F (2009) Transnational organized crime. Routledge, London 
Malleson N, Evans A (2013) Agent-based models to predict crime at places. In: Bruinsma G, Weisburd D (eds) Encyclopedia of criminology and criminal justice. Springer, New York, pp 243-252

Nardin LG, Andrighetto G, Conte R, Szekely A, Anzola D, Elsenbroich C, Lotzmann U, Neumann M, Punzo V, Troitzsch KG (2016) Simulating protection rackets: a case study of the Sicilian mafia. J Auton Agent Multi-Agent Syst: 1-31. doi:10.1007/s10458-016-9330-z

Neumann M, Sartor N (2016) A semantic network of laundering drug money. J Tax Adm 2(1):73-94

Neumann M, Frazzica G, Punzo V (forthcoming) Mechanisms of the embedding of extortion racket systems. The case of Cosa Nostra. In Stachowicz A, Mangia G (eds.). Organization Social Irresponsibility: tools and theoretical insights. Information age publishing, Charlotte

Novak A, Vallacher R, Burnstein E (1998) Computational social psychology: a neural network approach to interpersonal dynamics. In: Liebrand WBG, Nowak A, Hegselmann R (eds) Computer modelling of social processes. Sage, London, pp 97-125

Ostrom E (1990) Governing the commons: the evolution of institutions for collective action. Cambridge University Press, Cambridge

Paoli L (2003) Mafia Brotherhoods. Organized crime, Italian style. Oxford University Press, Oxford

Quirk P (1997) Macroeconomic implications of money laundering. Trends Organized Crime 2(3):10-14

Reckwitz A (2002) Toward a theory of social practices a development in culturalist theorizing. Eur J Soc Theory 5(2):241-263

Schatzki T (2002) Site of the Social? A philosophical account of the Constitution of Social Life and Change. Pennsylvania State University Press

Schelling T (1967) Economics and criminal enterprise. Public Interes 7:61

Ullmann-Margalit E (1977) The emergence of norms. Clarendon, Oxford

United national office on drugs and crime (2010) The globalization of crime. A transnational organized crime threat assessment. United nations publication, Vienna

Uslander E (2005) Trust and corruption. In: Lambsdorff J, Taube M, Schramm M (eds) The new institutional economics of corruption. Routledge, London, pp 76-92

van Putten C (2012) The process of extortion: problems and qualifications. Conference on Extortion Racket Systems. University of Vienna, Vienna: 3.-4. Dezember 2012. http://www.academia.edu/7465320/The_ process_of_extortion

Varese F (2014) Protection and extortion. In: Paoli L (ed) The Oxford handbook of organized crime. Oxford University Press, Oxford, pp 343-357

von Lampe K (1999) Organized crime: begriff und theorie organisierter kriminalität in den USA. Lang, Frankfurt a. M

von Lampe K (2001) Not a process of enlightenment. The conceptual history of organized crime in Germany and the United States of America. Forum Crime Soc 1(2):99-116

von Lampe K (2006) The interdisciplinary dimensions of the study of organized crime. Trends Organized Crime 9(3):77-95

von Lampe K (2013) Was ist organisierte Kriminalität? Aus Politik Zeitgesch 63(38/39):3-8

Voss T (2001) Game theoretical perspectives on the emergence of social norms. In: Hechter M, Opp KD (eds) Social norms. Russel Sage, New York, pp 105-137

Wimsatt W (1994) The ontology of complex systems: levels of organisation, perspectives, and causal Thickets. In: Matthen M, Ware R (eds). Canadian Journal of Philosophy, supp. Vol. 20, University of Calgary Press: 207-274 